\title{
IDENTIFICATION OF ANATOMY CONTENTS FOR MEDICAL STUDENTS USING DELPHI TECHNIQUE
}

\author{
Siti Munawaroh*, Gandes Retno Rahayu**, Efrayim Suryadi** \\ * Faculty of Medicine, Sebelas Maret University, Surakarta - INDONESIA \\ ** Faculty of Medicine, Universitas Gadjah Mada, Yogyakarta - INDONESIA
}

\begin{abstract}
Background: Anatomy is one of basic science in medicine. As doctors are obligated to assure their service is safe and efficient, they need to master anatomy science to support their work on comprehend the patient condition. In another condition, there is a shifting on medical curricula that impacted on decrease of anatomy instructional hours. This condition result in lower of anatomy academic achievement among medical students. The third of ten question Harden in curriculum development, that is what content should be included? need to be resolved so that the limited time available can be utilized as well as possible. This study aims to achieve national scope consensus among anatomical expert about anatomical material course that must be delivered to medical students.

Method: This study was design in qualitative approach with specified method of two round Delphi Technique. Using purposive sampling method, the subject of study involved was 20 experts of anatomical science in Indonesia. The questionnaire as instrument in this study arranged based on anatomy text book. The first Delphi purpose to select the anatomical course material and additional course material. The second Delphi round intent to provide level range from 1-4. The consensus level established by the researcher at $80 \%$ point. Results: The first Delphi round result in 760 anatomy topics consist of 636 original material arranged by researcher and 124 additional material added by the Delphi panel. Additional materials are osteomyology and sesnsory system. The second Delphi round agree 64\% material of first Delphi round (489).

Conclusion: Indonesian anatomical experts agree in which not all of anatomy material need to be learned by medical student. Their consensus is about $64 \%$ of all the material that must be learned.
\end{abstract}

Keywords: anatomy, core syllabus, expert consensus, Delphi method

\begin{abstract}
ABSTRAK
Latar belakang: Anatomi merupakan ilmu dasar dalam kedokteran. Anatomi penting dalam membantu dokter untuk lebih memahami kondisi penyakit pasien sehingga mendukung praktek dokter dilakukan secara efektif dan aman. Akan tetapi adanya perubahan kurikulum kedokteran menjadikan waktu yang tersedia dalam pembelajaran anatomi menjadi berkurang. Hal ini menjadi salah satu sebab pemahaman anatomi yang dimiliki oleh para calon dokter kurang memadai. Sehingga pertanyaan ketiga dari sepuluh pertanyaan Harden dalam pegembangan kurikulum, yaitu konten apa yang harus dimasukkan? perlu dicari jawabannya agar keterbatasan waktu yang ada bisa dimanfaatkan dengan sebaikbaiknya. Penelitian ini bertujuan untuk mendapatkan konsensus dari para ahli anatomi mengenai materi anatomi inti yang harus dimiliki oleh mahasiswa pendidikan dokter di Indonesia.

Metode: Penelitian ini merupakan penelitian kualitatif dengan menggunakan metode Delphi 2 putaran. Subyek penelitian adalah para pakar anatomi di Indonesia berjumlah 20 orang yang dipilih melalui purposiive sampling. Kuesioner awal disusun oleh peneliti berdasarkan tiga buku teks anatomi. Delphi putaran pertama panel diminta untuk memilih topik yang penting dan menambahkan jika ada topik yang belum ditulis. Delphi putaran kedua panel memberi rangking 1-4. Level konsensus yang ditetapkan peneliti sebesar $80 \%$.
\end{abstract}

contact: munafkuns@gmail.com 
Hasil: Pada Delphi putaran pertama terdapat tambahan topik sebanyak 124 dari kuesioner awal 636 topik sehingga total 760 topik. Tambahan terutama terdapat pada bagian osteomyology dan sistem sensori. Delphi putaran kedua didapatkan materi inti anatomi sebanyak 489 (64\%) dari 760 topik.

Kesimpulan: para ahli anatomi indonesia sepakat bahwa tidak semua materi anatomi perlu dipelajari oleh mahasiswa pendidikan dokter. Dari penelitian ini didapatkan konsensus pakar anatomi Indonesia ada sebanyak $64 \%$ materi inti anatomi dari keseluruhan anatomi tubuh manusia.

Kata kunci: anatomi, materi inti, konsensus pakar, metode Delphi

\section{INTRODUCTION}

For doctors, the human body is the focus of investigation and intervention in the basis of everyday practice. The main knowledge of anatomy is important and needs to be assimilated by all doctors to be able to practice and communicate safely. ${ }^{1}$ The understanding of the structures of human body, from the structures seen by naked eyes (macroanatomy) to the molecular level, are the basics to understand bodily functions and how normal structures and functions will change due to diseases. ${ }^{2}$ Good understanding about anatomy materials may help a doctor to be able to understand the condition of a patient's disease well. ${ }^{3,4}$ Therefore, a doctor can perform clinical examination and establish a patient's diagnosis, as well as perform clinical procedures effectively and safely. ${ }^{5}$

Several reports mentioned the reduced amount of time to learn anatomy for medical students. ${ }^{6}$ This reduction of time for anatomy learning has become an international trend. ${ }^{5} \mathrm{~A}$ comparison of a survey in 2009 with a survey in 2002 showed $11 \%$ of reduction. ${ }^{3}$ This was caused by the change of medical curriculum as the effect of the advancement of medical knowledge, ${ }^{7}$ newest changes in medical practice and the emergence of new diseases, ${ }^{8}$ as well as the changes of the ideas about which knowledge and skills are needed for prospective doctors for their future careers. ${ }^{7}$ Furthermore, the emergence of new sciences, such as genetics and molecular, took places in the curriculum. Additions of new materials were not balanced with the addition of study period for medical students. This caused changes in medical curriculum to include those materials. The chosen way was to reduce the hours of other materials, including anatomy. ${ }^{4,7}$
The understanding of anatomy of prospective doctors are considered inadequate. ${ }^{9}$ Surgeons reckoned that this was due to the reduced amount of time to learn anatomy. However, this is still debated about whether the decreased knowledge of anatomy was due to less allocated time or unsuitable methods ${ }^{1}$ or the difficult material contents. Because although anatomy is a basic science, many students complain of the difficulty of this material. ${ }^{10}$ Therefore, the main materials of anatomy have become a study subject in recent years. ${ }^{11}$

With above background, we should consider which anatomy knowledge that prospective doctors must at least have to practice safely. It aims to answer the third of the ten questions by Harden in curriculum development, what content must be included? In this case, according to Harden, the position of anatomy in medical curriculum is the building block, the knowledge required for someone to be able to understand other materials. For example, understanding the anatomy of the heart will help students to understand a patient's heart disease clinical condition. ${ }^{12}$ There are several studies about this. A majority of the studies used Delphi method, a method used to coordinate the communication process of a group to reach an effective process to get the solution of a complex problem. ${ }^{13}$ Among others are a study about the components of the anatomy of the bones that are relevant with clinical cases for medical students' learning, ${ }^{5}$ the development of the core materials about the anatomy of head and neck that need to be given to medical students, ${ }^{14}$ and the preparation of the core syllabus of anatomy for medical students, especially in neuroanatomy, ${ }^{7}$ as well as a study about the core syllabus of anatomy of 
the whole body. ${ }^{15}$ From all those studies, there is not a single one study about the materials of the anatomy of the whole body organized based on systems that needs to be given to medical students, especially in Indonesia.

This study aims to reach the consensus of anatomy experts about the core materials of anatomy that Indonesian medical students must have.

\section{METHODS}

This is a qualitative study using Delphi method. Subject selection used purposive sampling and involved 20 people with the inclusion criteria of teachers with medical background and already had a master's degree, already taught and assessed anatomy to medical students for at least 3 years, and had the experience of practicing as a general practitioner for at least 3 years. Meanwhile, the exclusion criteria established by the authors was: specialists, because they might be less objective about the materials of anatomy categorized as important for medical students.

The initial questionnaire made by the authors was based on a literature study on three textbooks, Gray's Anatomy by Drake et al., ${ }^{16}$ Clinically Oriented Anatomy by Moore et al., ${ }^{17}$ and Sobotta, Atlas of Human Anatomy, Latin Nomenclature. ${ }^{18}$ The resulted questionnaire was then consulted to an experienced anatomy expert, i.e. a professor of anatomy, already taught medical students for more than 35 years, and already had the title of PAK (Pakar Anatomi Kedokteran) from PAAI (Perhimpunan Ahli Anatomi Indonesia).

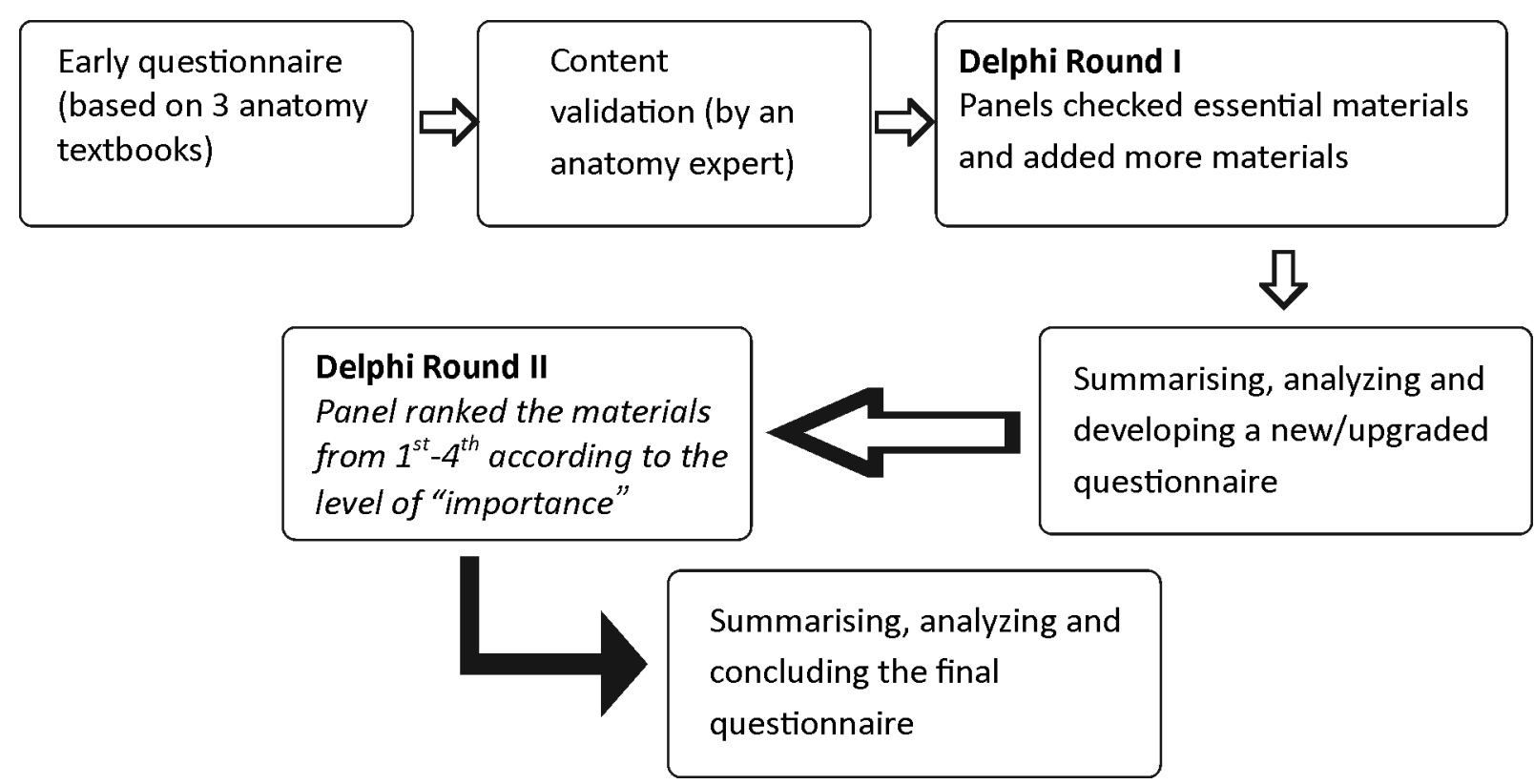

Figure 1. Research flow

When filling the questionnaire, both in Delphi round I or round II, Delphi panels were asked to pay attention to the established competence level of general practitioners in 2012 Standard Competence of Indonesian Doctors (SKDI).

There was an argument among experts about the percentage of agreement to use in a Delphi study. ${ }^{19,20}$
Therefore, authors decided to use the guide by Ulschak (1983) in Keeney et al. that determined 80\% of panels agreement in Delphi studies. ${ }^{19}$

The ethical clearance for this study was issued by the ethical committee of Dr. Moewardi Hospital No: 162/III/HREC/2016. 


\section{RESULTS AND DISCUSSIONS}

There were 20 subjects in this study, they were anatomy teachers of eight faculties of medicine in Indonesia who met the inclusion criteria. In the first round of Delphi, of the 20 questionnaires sent to subjects either directly or by emails, $16(80 \%)$ were returned to the authors. While in the second round, of the 16 questionnaires sent, 15 returned (93.75\%).

Table 1. Characteristics of the subjects

\begin{tabular}{|c|c|c|c|}
\hline No. & Characteristics & Number $(n)$ & Percentage (\%) \\
\hline \multirow[t]{3}{*}{1.} & Sex & & \\
\hline & Male & 8 & 50 \\
\hline & Female & 8 & 50 \\
\hline \multirow[t]{5}{*}{2.} & Age (years) & & \\
\hline & $30-39$ & 5 & 31.25 \\
\hline & $40-49$ & 9 & 56.25 \\
\hline & $50-59$ & 0 & 0 \\
\hline & $\geq 60$ & 2 & 12.50 \\
\hline \multirow[t]{4}{*}{3.} & Education & & \\
\hline & Master's degree & 11 & 68.75 \\
\hline & Doctoral degree & 4 & 25.00 \\
\hline & Professor & 1 & 6.25 \\
\hline \multirow[t]{5}{*}{4.} & Teaching experience (years) & & \\
\hline & $3-9$ & 5 & 31,25 \\
\hline & $10-19$ & 8 & 50.00 \\
\hline & $20-29$ & 1 & 6.25 \\
\hline & $\geq 30$ & 2 & 12.50 \\
\hline \multirow[t]{5}{*}{5.} & Practicing experience as a general practitioner (years) & & \\
\hline & $3-9$ & 7 & 43.75 \\
\hline & $10-19$ & 6 & 37.50 \\
\hline & $20-29$ & 1 & 6.25 \\
\hline & $\geq 30$ & 2 & 12.50 \\
\hline
\end{tabular}

The questionnaire consisted of 10 bodily systems. Those systems were divided into 636 anatomy materials. In the first round, there were 124 added topics from the Delphi panel, with a total of 760 topics. The detail of each system is presented in Table 2 below. 
Table 2. The number of new topics added in Delphi round I

\begin{tabular}{llccc} 
No. & \multicolumn{1}{c}{ Bodily System } & $\begin{array}{c}\text { Initial } \\
\text { questionnaire }\end{array}$ & $\begin{array}{c}\text { Number of } \\
\text { new topics }\end{array}$ & $\begin{array}{c}\text { Results of Delphi } \\
\text { round I }\end{array}$ \\
\hline General Anatomy & 6 & 3 & 9 \\
Osteomyology & 154 & 67 & 221 \\
Nervous System & 35 & 6 & 41 \\
Cardiovascular System & 59 & 3 & 62 \\
Respiration System & 77 & 2 & 79 \\
Digestive System & 117 & 9 & 126 \\
Urologic System & 38 & 3 & 41 \\
Female Genital System & 63 & 7 & 70 \\
Male Genital System & 73 & 5 & 78 \\
Sensory System & 14 & 19 & 33 \\
\hline Total & 636 & 124 & 760 \\
\hline
\end{tabular}

Delphi round II resulted in 489 core materials from a total of 760 anatomy materials or about $64 \%$. Meanwhile, the materials not included into the core materials were $271(36 \%)$. The detail of the number of the core materials for each bodily system is presented in Table 3

Table 3. The number of core topics in each bodily system

\begin{tabular}{llcc} 
No $\quad$ Bodily System & $\begin{array}{c}\text { Number of initial } \\
\text { topics }\end{array}$ & $\begin{array}{c}\text { Number of core } \\
\text { topics }\end{array}$ \\
\hline General Anatomy & 9 & 3 \\
Osteomyology & 221 & 85 \\
Nervous System & 41 & 38 \\
Cardiovascular System & 62 & 56 \\
Respiration System & 79 & 62 \\
Digestive System & 126 & 87 \\
Urologic System & 41 & 33 \\
Female Genital System & 70 & 45 \\
Male Genital System & 78 & 52 \\
Sensory System & 33 & 28 \\
Total & 760 & 489 \\
\hline
\end{tabular}

The examples of the core materials are shown in Table 4 . 
Table 4. Examples of the list of general anatomy topics in the core materials

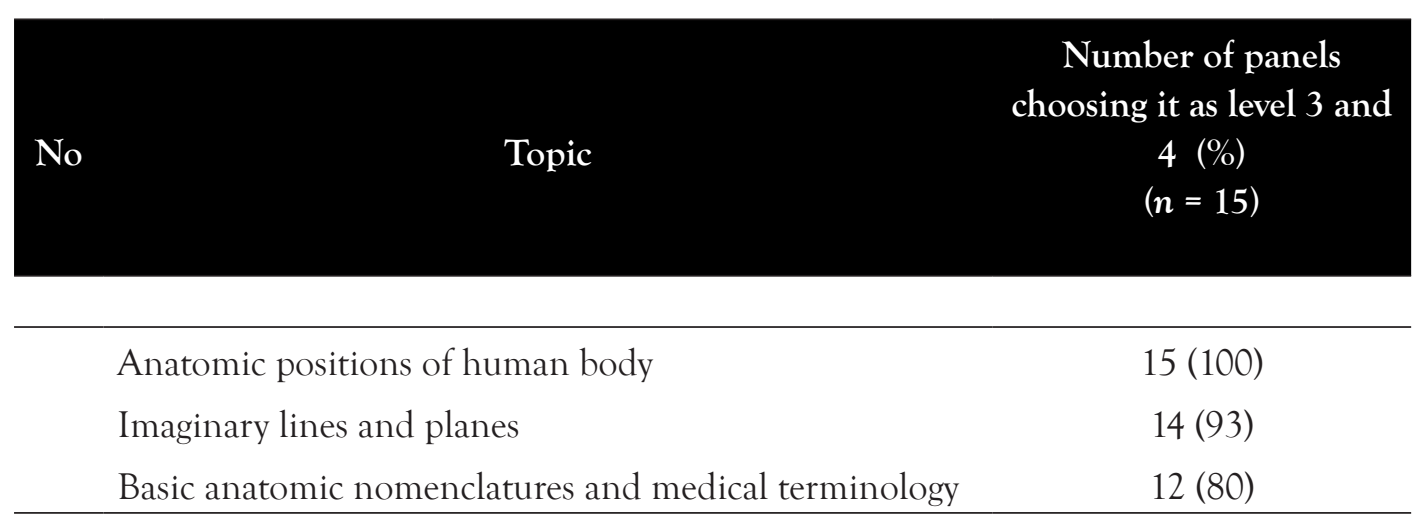

The initial questionnaire in this study was compiled by the authors based on textbooks. This is in line with the study by Moxham et al. ${ }^{7}$ about neuroanatomy, and Smith et al..$^{15}$ about anatomy of each human body region. By using this method, all materials were expected to be compiled completely without missing parts. This is different from the study by Swamy et al where they compiled the list of anatomy materials from first round Delphi panels to ensure the written materials were materials most often needed based on clinical cases during practice. ${ }^{5}$

Each Delphi panel had different opinions, both in first and second round. Some Delphi panels considered a topic important for medical students to learn, while other panels considered it unimportant, and vice versa. Therefore, the authors needed to determine the agreement used in this Delphi study. ${ }^{19,20}$ Therefore, authors decided to use the guide by Ulschak ${ }^{19}$ to determine $80 \%$ of panel agreement in a Delphi study. This percentage of agreement was the same with what Lisk used in their study about anatomy materials of musculoskeletal system for residents of rehabilitation in Canada using Delphi method. However, this percentage of agreement is different from a study about the anatomy of orthopedics for medical students which used a quite high percentage of $94 \%,{ }^{5}$ and in a study about human body anatomy of each region which used $90 \% .{ }^{15}$ On the other hand, lower agreement also found which are a study about neuroanatomy established a limit of $60 \%$ agreement ${ }^{7}$ and a study about the anatomy of head and neck established a quite low limit of $50 \% .^{14}$
In the first round of Delphi, there were many new materials added by the Delphi panels, especially in osteomyology with 67 topics. This was because not all osteomyology materials were included in the material list in the first round. The materials omitted by the authors were mostly about the small joints in the body.

The materials of osteomyology in the second round of Delphi had 85 core materials from all 221 topics from the first round of Delphi. So, there were a total of 136 materials omitted from the core materials. The majority of the topics omitted from the core materials were the components of small joints. This was maybe because Delphi panels had the same opinion with the authors and the consultant expert that those materials were not the materials needed to be emphasized in learning. Students needed the general concept only, not detailed. More detailed learning might be given in master's degree level of macroanatomy in basic medical science or in orthopedic specialist education.

The materials of sensory system in the first round Delphi also had many added materials from the Delphi panels with 19 new topics. This was because authors avoided duplicated materials. For example, the components of the nose materials were already written in the respiration system and the tongue in the digestive system, so they did not need to be re-written in the sensory system. However, Delphi panels had a different view. Although the same organ was discussed, different systems would put different emphasis on the discussion. 
Organ embryology in all bodily systems did not make it to the core materials. This was the agreement of anatomy experts that were the Delphi panels in this study. Different opinion was given by Carlson in his article titled "Embryology in the medical curriculum". He mentioned that the understanding of embryology was important for a doctor, especially when facing a patient with a congenital disability. The understanding of embryology is useful to understand the causes of abnormal development and how development process in that case deviate from normal. ${ }^{21}$ In addition, Scott et al..$^{22}$ in a study about medical students' attitude in the final year of education who had embryology learning using clinical scenario also mentioned that embryology was important for medical students. ${ }^{22}$ This difference might be because panels rarely faced cases that needed the understanding of embryology in general practice. Furthermore, most cases of disease are related to embryology fall into competence level 1 or 2 , so they are not general practitioners' competence.

The resulted core materials of anatomy in this study were suited according to the needs of doctors when practicing in the field after graduating. A few of the efforts by the authors to direct to this objective was to establish the criteria of Delphi panels selection as well as to plan the procedure to perform Delphi round I and II.

Authors decided to include a practice experience as a general practitioner as an inclusion criteria. With an experience of practicing as a general practitioner, panels could reflect their experiences when facing patients, doing anamnesis, performing clinical examinations, performing clinical procedures, giving therapies, and so on, so those experiences might help their selection of anatomy material topics whether they were important for students to learn or not.

In this study process of filling questionnaires, both in Delphi round one or two, panels were asked to pay attention to doctors' competence level established in the 2012 Standard Competence of Indonesian Doctors (SKDI). SKDI is the minimum standard competence of doctor graduates that is revised periodically, adjusted with the development related to healthcare system synergism with medical education system, the development in the society, as well as the development of sciences and medical technology. ${ }^{23}$

It is a general knowledge that anatomy is rich of information. ${ }^{24}$ If all information is given to medical students, there will be an overload. This is because human brains have the limits to save memory. ${ }^{25}$ In cognitive load theory, received materials are included in intrinsic factors that must be managed. Material overload received by students may cause decreased retention ability. Therefore, we need to sort out and choose exactly which materials are important to learn and which ones are enough to just be known. The resulted consensus in this study is expected to be able to help anatomy teachers to select which materials to learn for medical students.

Anatomy is a basic science in medical education. Undoubtedly, anatomy knowledge is important for doctors regardless of their specialization. This is mainly because they keep performing physical examinations, making medical decisions, communicating with colleagues, and giving explanations to patients and these may work effectively and safely if doctors understand anatomy well. ${ }^{27}$ Therefore, anatomy learning should not stop at the bachelor level of medical education. Specialist education also needs deeper anatomy understanding, especially in their specialization area. For example, an orthopedist needs deeper understanding about osteomyology more compared to bachelor medical students. In this study, for example, because this study was intended for bachelor medical students, many materials about small joints in the body were omitted in the core materials because the understanding of this would suit better and be needed more by orthopedists. Besides specialist education, anatomy materials that did not make it in the core materials also may be given in the education of master's degree in basic medical science of macroanatomy. Similar opinion was also expressed by Hirt and Shiozawa ${ }^{28}$ in their review titled "Clinical anatomy as a modern concept for $21^{\text {st }}$ century teaching, postgraduate education, and research". They mentioned that anatomy learning was given to bachelor, postgraduate, and specialist education students. 
One of the advantages of this study was that the involved Delphi panels were from many faculties of medicine in Indonesia, so this study represented Indonesian anatomy experts enough. However, the results did not have enough power to recommend them to medical education institutions throughout Indonesia. Therefore, PAAI needs to be involved as the institution officially recognized by all departments of anatomy in all faculties of medicine in Indonesia. These results were expected to be a suggestion for PAAI in preparing anatomy curriculum for bachelor medical education, so they did not need to start over.

Several things that may be done by PAAI team in continuing this study is to give more details about the resulted core materials because this study mentioned some anatomy materials grossly, not detailed into structures, so it is still difficult to determine how far students can learn those materials. The example is the names of throat and neck muscles. Are all muscles in throat and neck area must be learned by students or do students need more emphasis on certain muscles often related to clinical cases, for instance is the sternocleidomastoideus muscle. So, the recommendation for future studies is to make more details of each human body structure. This may be the third round of Delphi.

Anatomy learning by relating to real clinical conditions where the understanding is needed will grow students' urge to do deep learning. By deep learning, students will try actively to seek meanings and to understand what they learn. ${ }^{24} \mathrm{~A}$ deep learner does not only memorize a concept, but also try to relate a concept with another. Anatomy learning with deep learning approach will help to understand and maintain that memory retention throughout life. ${ }^{29}$ The limitation of this study is this study did not mention the details of clinical conditions related to the importance of an anatomy topic. The reason column from the authors were mostly answered with only a short answer by the Delphi panels.

Delphi panel 6: the reason to select upper extremity morphology in level 4 is: the basis of clinical science.

Delphi panel 5: the reason to select extraocular muscles in level 4 is: to know clinical disorder.
Therefore, in the following stage, curriculum team may perform Delphi round four to dig what clinical cases need that certain anatomy material understanding, so students' learning process may be contextual to increase anatomy materials retention that they learn. To relate to SKDI more, this relatedness may be dug into more details that an anatomy topic may be advantageous in helping students to understand health problem $\mathrm{A}$, disease $\mathrm{P}$, or clinical skill X.

Anatomy is a basic science in health subject. Not just in medical education, anatomy is also needed in other health professions education, such as nurse, midwife, dentist, pharmacist, and so on. ${ }^{30}$ The difference would be the focus to learn. However, just like anatomy for bachelor medical education that does not have standard curriculum yet, that is also the case with other professions. Therefore, this study is expected to be the start of further studies for anatomy learning in other health professions education.

This study is part of "curriculum development" studies to answer Harden's third of ten questions in curriculum development: what are the contents to be included? ${ }^{12}$ The approach to answer this question was the "wiseman approach" by placing anatomy teachers/experts as the "wiseman". This method may also be applied in other disciplines, such as physiology, histology, and others.

\section{CONCLUSION}

Anatomy experts' consensus in this study is that there are 489 core anatomy materials of all 760 anatomy materials (64\%) that need to be learned by medical students. This result is the core materials that is the minimum knowledge a prospective doctor must have to be able to practice effectively and safely and is already adjusted to suit doctors' needs to practice in the future and to suit the competence level in 2012 SKDI.

\section{ACKNOWLEDGEMENT}

Authors thank Faculty of Medicine, Universitas Sebelas Maret and Faculty of Medicine, Universitas Gadjah Mada for the support in this study. Authors 
also thank Prof. Dr. Didik Gunawan Tamtomo dr., PAK, MM, M.Kes who gave many inputs in the questionnaire preparation. Authors also thank anatomy associates in Indonesia for the willingness to be panels in this study.

\section{REFERENCES}

1. Turney B. Anatomy in a modern medical curriculum. The Royal College of Surgeons of England. 2007; 89:1047.

2. McCuskey RS, CarmichaelSWKDG. The Importance of Anatomy in Health Professions Education and the Shortage of Qualified Educators. Academic Medicine. 2005; 80(4): 349-51.

3. Drake R, McBride J, Lachman A, Pawlina W. Medical education in the anatomical sciences: the winds of change continue to blow. Anat Sci Educ. 2009; 2: p. 253-259.

4. The Education Committee of the Anatomical Society of Great Britain and Ireland. A core syllabus in anatomy for medical students - Adding common sense to need to know. Eur J Anat. 2007; 11: 3-18.

5. Swamy M, Venkatachalam S, McLachlan J. A Delphi consensus study to identify current clinically most valuable orthopaedic anatomy components for teaching medical students. BMC Medical Education. 2014;14(230):1-5.

6. Ganguly PK. Teaching and Learning of Anatomy in the 21st century: Direction and the strategy. The Open Medical education Journal. 2010; 3:5-10.

7. Moxham BJ, Plaisant O, Smith CF, Pawlina W, McHanwell S. An Approach Toward the Development of Core Syllabuses for the Anatomical Sciences. Anatomical Sciences Education. 2014; 7:302-11.

8. Klement BJ, Paulsen DF, Wineski LE. Anatomy as the Backbone of an Integrated First Year Medical Curriculum: Design and Implementation. Anat Sci Educ. 2011; 4(3):157-69.

9. Bergman EM, Vleuten CPMVD, Scherpbier AJJA. Why don't they know enough about anatomy? A narrative review. Medical Teacher. 2011; 33:403-9.

10. Munawaroh S. Penggunaan 4C/ID dan active learning dalam pembelajaran anatomi dalam large group. Jurnal Pendidikan Kedokteran Indonesia. 2015 Maret; 4(1).

11. Ball JJ, Napuli KLP, Zumpano M. An International Survey of Gross Anatomy Courses in Chiropractic
Colleges. The Journal of Chiropractic Education. 2012; 26(2):175-83.

12. Harden RM. Ten questions to ask when planning a course or curriculum. Medical Education. 1986; 20:356365.

13. Linstone HA, Turoff M. The Delphi Method Techniques and Applications: Addison Wesley Educational Publisher Inc; 2002.

14. Tubbs R, Sorenson E, Sharma A, Benninger B, Norton N, Loukas M, et al. The development of a core syllabus for the teaching of head and neck anatomy to medical students. Clin. Anat. J. 2014;27(3):321-30.

15. Smith CF, Finn GM, Stewart J, McHanwell S. Anatomical Society core regional anatomy syllabus for undergraduate medicine: the Delphi process. Journal of Anatomy. 2016;228:2-14.

16. Drake RL, Vogl W, Mitchell AWM. Gray's Anatomy for Student: Elsevier; 2007.

17. Moore KL, Dalley AF, Agur AMR. Clinically Oriented Anatomy. 7th ed. London: Lippincott williams \& wilkins Wolters Kluwer; 2014.

18. Sobotta J. Sobotta, Atlas of Human anatomy. 15th ed. Paulsen F, Waschke J, editors. Munich: Elsevier; 2010.

19. Keeney S, Hasson F, McKenna H. The Delphi Technique in Nursing and Health Research Malaysia: A John Wiley \& Sons, Ltd., Publication; 2011.

20. Hasson F, Keeney S, McKenna H. Research guidelines for the Delphi survey technique. Journal of Advanced Nursing. 2000; 32(4):1008-15.

21. Carlson BM. Embryology in the Medical Curriculum. The Anatomical Record (New Anat). 2002;269:89 -98.

22. Scott KM, Charles AR, Holland AJA. Clinical embryology teaching: is it relevant anymore? ANZ of Journal Surgery. 2013;83:709-12.

23. KKI. Standar Kompetensi Dokter Indonesia (SKDI). 2nd ed. Indonesia: Konsil Kedokteran Indonesia; 2012.

24. Louw G, Eizenberg N, Carmichael SW. The place of anatomy in medical education: AMEE Guide no 41. Medical Teacher. 2009;31:373-86.

25. Sweller J. How the Human Cognitive System Deals with Complexity. In Elen J, Clark RE, editors. Handling Complexity in Learning Environments: Theory and Research. Netherlands: Elsevier; 2006. p. 13-26. 
26. Debue N, Leemput Cvd. What does germane load mean? An empirical contribution to the cognitive load theory. Frontiers in Psychology. 2014;5:1-12.

27. Cho MJ, Hwang Yi. Students' perception of anatomy education at a Korean medical college with respect to time and contents. Anatomy and Biology Cell. 2013;46:157-62.

28. Hirt B, Shiozawa T. Clinical anatomy as a modern concept for 21st century teaching, postgraduate education, and research. Kitasato Med J. 2013; 43. 2013; 43:99-103.

29. Meester LD. Learning Anatomy for Use Beyond the Classroom: A Guide for Medical. McMaster University Medical Journal. 2011; 8(1):45-8.

30. Drake, Vogl and Mitchell. Gray's Basic Anatomy. 1st ed. Singapore: Elsevier Churcill Livingstone; 2012. 